\title{
References
}

Dawson, J. B. (1967) A review of the geology of kimberlite. In Wyllie, P. J. (edit.) Ultramafic and related rocks, 241-251. London: Wiley.

Emeleus, C. H. (1958) The granites of the Tigssalug area, S. W. Greenland. Unpubl. rep., Grфnlands geol. Unders.

Larsen, O. and M $\varnothing l l e r$, J. (1968) K/Ar age determinations from western Greenland I. Reconnaissance programme. Rapp. Grønlands geol. Unders., Nr. 11, 82-86.

Lee, H. A. and Lawrence, D. E. (1968) A new occurrence of kimberlite in Gauthier Township, Ontario. Geol. Surv. Can. Paper 68-22.

Nixon, P. H., Knorring O. von and Rooke, J.M. (1963) Kimberlites and associated inclusions of Basutoland; a mineralogical and geochechemical study. Amer. Min。, Vol. 48, 1090-1132.

Walton, B.J. (1966) Carbonatite-lamprophyre dykes of Mesozoic age. Rapp. Grфnlands geol. Unders., Nr. 11, 37-38.

\section{FIELD WORK IN THE ILÍMLAUSSAQ INTRUSION}

\section{H. S $\phi r e n s e n$}

In the summer of 1968 the detailed mapping at scale $1: 2000$ of the Kvanefjeld region in the northernmost part of the intrusion was practically completed. During this study four types of uranium deposits have been established:

1. A zone of contact alteration around late veins and sheets of a medium - to coarse-grained lujavrite which is confined to a horizon between the roof of gabbro, lava, etc. and an underlying zone of syenites veined by fine-grained lujavrite (cf. S $\phi$ rensen, Hansen and Bondesen, 1969). This deposit was examined in $36 \mathrm{drill}$ holes in 1958 and found to contain 4000 tons 
$\mathrm{U}$ in the region delineated by these drill holes. During the examinations carried out from 1964 to 1968 this deposit has been traced farther to the east and may also occur hidden under the roof to the north-east of the exposed part of the deposit. The average contents of $U$ and $T h$ of this deposit are $575 \mathrm{ppm} U$ and $1920 \mathrm{ppm} \mathrm{Th}$. The maximum values found are $3000 \mathrm{ppm}$ $\mathrm{U}$ and $13000 \mathrm{ppm}$ Th.

2. The syenites, naujaite, gabbro, lavas, etc. of the region are veined by fine-grained lujavrites which locally contain more than $300 \mathrm{ppm} \mathrm{U}$. These veins are generally so thin and the contents of $U$ and $T h$ so variable that these deposits are considered uneconomical at the moment.

3. In the easternmost part of the Kvanefjeld region zones of deformation in gabbro and lava are permeated by fine-grained lujavrite and also by veins recalling veins associated with the above-mentioned medium - and coarse-grained lujavrites. They may therefore be underlain by rocks of this type. These zones are enriched in $U$ and $T h$ having about $500 \mathrm{ppm} U$ and $1900 \mathrm{ppm}$ Th.

4. In the northernmost part of the Kvanefjeld region, near the contact with the lavas of the country rocks, a body of brownish-green lujavrite, in part naujakasite-bearing, is cut by pegmatitic veins of the type associated with the medium- to coarse-grained lujavrite of type 1. This body contains more than $600 \mathrm{ppm} \mathrm{U}$ and more than $3000 \mathrm{ppm}$ Th.

A new drilling programme in the deposits of types 1,3 and 4 is planned for 1969 .

In addition to the work carried out in the Kvanefjeld region other field teams examined the layered kakortokite (C. K. Brooks and H. Bohse, this report), the border pegmatites of the intrusion (Agnette S. Westergaard, this report), the water balance in the Narssaq river valley, a number of localities rich in rare minerals (also including Narssarssuk in the Igaliko intrusion) and the transition naujaite-sodalite foyaite at Tuperssuatsiaq.

Reference

Sørensen, H., Hansen, J. and Bondesen, E. (1969) Preliminary account of the geology of the Kvanefjeld area of the Ilímaussaq intrusion, South Greenland. Rapp. Grфnlands geol. Unders., Nr. 18. 